\title{
ZODPOVEDNOSŤ LETECKÝCH DOPRAVCOV A PRÁV
}

A CESTUJÚCICH

\section{LIABILITY OF AIR CARRIERS AND PASSENGER RIGHTS}

\section{Rastislav Funta ${ }^{1}$}

DOI: https://doi.org/10.24040/pros.13.11.2020.svp.61-76

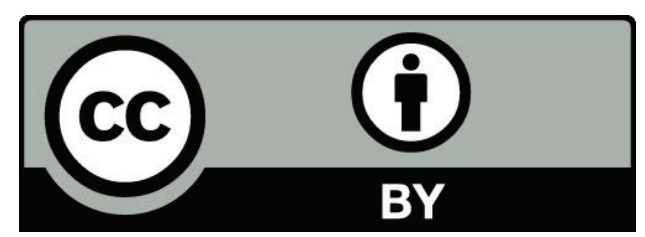

\begin{abstract}
Abstrakt
Rôzne právne rámce a ideológie ovplyvnili rozvoj viacúrovňovej regulácie civilného letectva vzhl'adom na ochranu spotrebitel'a a režimov obmedzenej zodpovednosti. Takýto vývoj sa odráža v pokroku na medzinárodnej úrovni po tom, čo medzinárodná organizácia pre civilné letectvo prijala základné zásady ochrany cestujúcich v leteckej doprave. Tento článok diskutuje o ochrane spotrebitel'a a zodpovednosti leteckých dopravcov v oblasti leteckej dopravy. Článok sa rovnako zaoberá existujúcim medzinárodným právom v oblasti zodpovednosti leteckých dopravcov a režimami práv cestujúcich $v$ EÚ a USA.
\end{abstract}

\section{Kl’účové slová}

Ochrana spotrebitel’a, medzinárodná organizácia civilného letectva, zodpovednost' leteckých dopravcov, EU, USA

\begin{abstract}
Different legal frameworks and ideologies have influenced the development of multi-level civil aviation regulation with regard to consumer protection and limited liability regimes. Such developments are reflected in progress at international level after the adoption by the International Civil Aviation Organization of the basic principles of the protection of air passengers. This article discusses consumer protection and air carriers' liability in the field of air transport. The article also addresses existing international airline liability law and EU and US passenger rights regimes.
\end{abstract}

\section{Keywords}

Consumer Protection, International Civil Aviation Organization, Airline Liability, EU, USA

\footnotetext{
${ }^{1}$ Doc. JUDr. Rastislav FUNTA, Ph.D., LL.M.; Vysoká škola Danubius, Richterova č. 1171, 92521 Sládkovičovo, Slovenská republika, e-mail: rastislav.funta@vsdanubius.sk
} 


\section{PRÁVNE ROZPRAVY ON-SCREEN II. - Sekcia verejného práva}

online vedecká konferencia - 13. november 2020

\section{Úvod}

V priebehu posledných rokov došlo k postupnému nárastu práv cestujúcich v leteckej doprave. Príkladom je napr. zákon o právach cestujúcich v leteckej doprave (USA); zákon o ochrane práv spotrebitel’ov (Ruská federácia), pravidlá pre cestujúcich a batožinu v civilnom letectve (Č́na); nariadenie o ochrane spotrebitel’ov (Saudská Arábia); zákon o právach cestujúcich v leteckej doprave (Izrael) a pod. V rámci práva Európskej únie $(E U ́)^{2}$ platí nariadenie Európskeho parlamentu a Rady (ES) č. 261/2004³ ktorým sa ustanovujú spoločné pravidlá o kompenzáciách a pomoci cestujúcim v prípade odmietnutia nástupu do lietadla a zrušenia alebo vel'kého meškania letov. Zatial' čo iniciatívy na ochranu spotrebitel'a tradične vychádzali z politických reakcií na domáce obavy, ako sú nekalé zmluvné podmienky a škody spôsobené chybnými výrobkami, súčasné právne predpisy sa týkajú "špecializovaných" práv spotrebitel'ov. Príslušné právne predpisy EÚ v tejto oblasti zahŕňajú smernicu 2005/29/ES ${ }^{4}$ o nekalých obchodných praktikách podnikatel'ov voči spotrebitel'om na vnútornom trhu a smernicu $2011 / 83^{5}$ o právach spotrebitel'ov. Špecifické usmernenia boli vydané v roku 2016 v oblasti "cestovného ruchu". ${ }^{6} \mathrm{Na}$ medzinárodnej úrovni boli usmernenia OSN o ochrane spotrebitel'a prijaté konsenzom v roku 1985 po tom, ako v roku 1975 vyzvala Consumer International (neskôr Medzinárodná organizácia spotrebitel'ských zväzov), aby vytvorila vzorový kódex ochrany spotrebitel'a. ${ }^{7} \mathrm{Z}$ obavy o rýchle šírenie národných právnych predpisov v špecializovanej oblasti práv cestujúcich $\mathrm{v}$ leteckej doprave medzinárodné spoločenstvo vyzvalo Medzinárodnú organizáciu civilného letectva (ICAO) ${ }^{8}$ v roku 2013 aby vyvinulo "súbor základných zásad ochrany spotrebitel’ov", ktorými sa má na národnej úrovni dosiahnut' "primeraná rovnováha medzi ochranou spotrebitel'a a celkovou konkurencieschopnost'ou, pri zohl’adnení potreby štátov vzhl'adom na rôzne sociálne, politické a ekonomické charakteristiky;

\footnotetext{
${ }^{2}$ MAZÁK, J. - JÁNOŠÍKOVÁ, M. Základy práva Európskej únie. 2009.

${ }^{3}$ Nariadenie Európskeho parlamentu a Rady (ES) č. 261/2004 z 11. februára 2004, ktorým sa ustanovujú spoločné pravidlá o kompenzáciách a pomoci cestujúcim v prípade odmietnutia nástupu do lietadla a zrušenia alebo vel'kého meškania letov. Po prepuknutí ochorenia COVID-19 Európska komisia schválila Oznámenie Komisie Výkladové usmernenia $\mathrm{k}$ predpisom EÚ o právach cestujúcich v kontexte vývoja situácie COVID-19 a Odporúčanie Komisie (EÚ) 2020/648 z 13. mája 2020 týkajúce sa poukazov ponúkaných pasažierom a cestujúcim ako alternatívnu náhradu za zrušené balíky cestovných služieb a dopravné služby v súvislosti s puandémiou COVID-19.

${ }^{4}$ Smernica Európskeho parlamentu a Rady (ES) č. 2005/29/ES z 11. mája 2005 o nekalých obchodných praktikách podnikatel'ov voči spotrebitel'om na vnútornom trhu.

${ }^{5}$ Smernica Európskeho parlamentu a Rady (ES) č. 2011/83 z 25. októbra 2011 o právach spotrebitel'ov.

${ }^{6}$ Usmernenia OSN pre ochranu spotrebitel'a, 2016.

${ }^{7}$ Usmernenia OSN pre ochranu spotrebitel'a, 2003.

${ }^{8}$ MRÁZ, S. - POREDOŠ, F. - VRŠANSKÝ, P. Medzinárodné verejné právo. 2003.
} 


\section{PRÁVNE ROZPRAVY ON-SCREEN II. - Sekcia verejného práva}

online vedecká konferencia - 13. november 2020

s existujúcimi nástrojmi." Medzinárodné právo existuje v oblasti zodpovednosti leteckých dopravcov podl'a Montrealského dohovoru z roku 1999, ktorý stanovuje dvojstupňový režim zodpovednosti za "nehody", ku ktorým došlo počas uplatňovania medzinárodnej zmluvy o preprave cestujúcich, batožiny a nákladu: objektívna zodpovednost' a prezumpcia zodpovednosti. ${ }^{9} \mathrm{~S}$ ciel'om lepšieho pochopenia je potrebné rozvinút' chápanie pojmov "práva cestujúcich v leteckej doprave" a "zodpovednost' leteckého dopravcu". ${ }^{10} \mathrm{~V}$ úvode budeme identifikovat' existujúcé medzinárodné právo týkajúce sa zodpovednosti leteckých dopravcov v súvislosti so zmluvami o leteckej preprave cestujúcich, batožiny a nákladu. Ďalej uvedieme hlavné zásady ochrany spotrebitel'a, ktoré boli prijaté ICAO. Predtým ako zameriame diskusiu na štyri vybrané kritériá, ktoré by mali riadit’ režimy práv cestujúcich v leteckej doprave, preskúmame súčasné právne predpisy EÚ a USA týkajúce sa cestujúcich v leteckej doprave.

\section{Súčasné medzinárodné právo: Varšava a Montreal}

ICAO je špecializovaná agentúra OSN zodpovedná za rozvoj medzinárodnej leteckej dopravy. ${ }^{11}$ ICAO prijala Dohovor o zjednotení niektorých pravidiel pre medzinárodnú leteckú dopravu (Montrealský dohovor) z roku 1999 ako nástupca pôvodného dohovoru o zodpovednosti leteckých dopravcov, Varšavský dohovor z roku 1929. Varšavský dohovor vytvoril prvý jednotný medzinárodný systém pravidiel na svete pre medzinárodnú leteckú prepravu, vrátane obmedzení zodpovednosti leteckého dopravcu. Praktickým prínosom pre cestujúcich a prepravcov bola ochrana; prepravcom bol definovaný rozsah ich zodpovednosti.

Montrealský dohovor zavádza modernizovaný kompenzačný režim pre cestujúcich a prepravcov prostredníctvom zjednodušeného systému obmedzenej zodpovednosti za leteckú prepravu a prepravu cestujúcich. ${ }^{12}$ Nadobudnutím účinnosti v roku 2003 Montrealský dohovor zavádza dvojstupňový systém zodpovednosti za "nehody". Prvý stupeň stanovuje prísnu zodpovednost' leteckých spoločností, ktorá je obmedzená na 131.100 SDR (približne 176.000 USD) za smrt' alebo zranenie cestujúcich. Druhý stupeň poskytuje predpokladanú zodpovednost' v neobmedzenej výške. Letecký dopravca sa môže odvolat' v prípade že môže preukázat', že škoda

\footnotetext{
${ }^{9}$ Dohovor o zjednotení niektorých pravidiel pre medzinárodnú leteckú dopravu z 28. mája 1999 (Montrealský dohovor).

${ }^{10}$ HAVEL, G. The Principles and Practice of International Aviation Law. 2014.

${ }^{11}$ BARTSCH, I. International Aviation Law: A Practical Guide. 2012.

${ }^{12}$ HAMILTON, S. Practical Aviation Law. 2011.
} 


\section{PRÁVNE ROZPRAVY ON-SCREEN II. - Sekcia verejného práva}

online vedecká konferencia - 13. november 2020

nebola spôsobená jeho nedbanlivost'ou alebo protiprávnym konaním. V prípade leteckého nákladu je zodpovednost' leteckého dopravcu obmedzená dohovorom podl'a váhy: 19 SDR za kilogram. Podl'a ustanovení Varšavského dohovoru bola "nehoda" definovaná ako "Škoda vzniknutá v prípade smrti alebo zranenia cestujúceho alebo akejkol’vek iná telesná ujma, ktorú utrpel cestujúci". ${ }^{13}$ Montrealský dohovor stanovuje zodpovednost' leteckého dopravcu za "Škody vzniknuté v prípade smrti alebo zranenia", ale iba vtedy, ak "nehoda" ktorá mala za následok smrt' alebo zranenie sa stala na palube lietadla alebo v priebehu nastupovania alebo vystupovania. Čo sa teda podl'a tohto predpisu rozumie pod nehodou? Situácia zahŕňajúca pohodený plastový obal na deku na podlahe lietadla, ktorý spôsobí, že cestujúci sa pošmykne a utrpí zranenie, nie je v zmysle Montrealského dohovoru zaradený pod "nehodu", pretože to nepredstavuje "neobvyklú alebo neočakávanú udalost". ${ }^{14}$ Rozhodujúcim je existencia príčinnej súvislosti medzi nehodou a vznikom ujmy; udalost' musí byt' kvalifikovaná ako "nehoda". Nárok uplatnený v zmysle Montrealského dohovoru podlieha ovel’a štedrejším úrovňam kompenzácie za smrt' alebo zranenie osôb, ako v rámci Varšavského systému; limity sú predmetom preskúmania každých pät' rokov. Montrealský dohovor zrušil obmedzenia Varšavského systému. Tie sa považovali za svojvol’né, a boli nahradené dvojstupňovým prísnym režimom zodpovednosti.

Zámerom bolo, aby bol celý Varšavský systém nahradený Montrealským dohovorom. Celkový počet členských štátov ICAO je 193. Vzhl'adom na to, že väčšina štátov s vel'kým významom pre leteckú dopravu je už signatárom Montrealského dohovoru, existuje relatívne dobré globálne pokrytie. V leteckom priemysle sa však vyskytujú obavy, že v skutočnosti je úrovneň uplatňovania a presadzovania neuspokojivá. ${ }^{15} \mathrm{~V}$ dôsledku toho podla Medzinárodnej asociácie leteckých prepravcov (IATA), ktorá reprezentuje letecké spoločnosti, je to výsledkom "existencie rôznych režimov zodpovednosti, ktoré mali byt' nahradené nad'alej existujú po celom svete. To znamená, že cestujúci v mnohých prípadoch nemajú možnost' zvýšenej ochrany ktorú poskytuje Montrealský dohovor ... [a] rovnako letecké spoločnosti a prepravcovia nemôžu využívat' významné výhody, ktoré ponúka Montrealský dohovor". ${ }^{16}$ Zdá sa, že práve tento nedostatok spoločného globálneho prístupu prinútil štáty reagovat' vo forme výzvy na vypracovanie základných zásad v rámci medzinárodného fóra, ICAO.

\footnotetext{
${ }^{13}$ Dohovor o zjednotení niektorých pravidiel týkajúcich sa medzinárodnej leteckej dopravy (1929).

${ }^{14}$ Dohovor o zjednotení niektorých pravidiel pre medzinárodnú leteckú dopravu z 28. mája 1999 (Montrealský dohovor), čl. 17.

${ }^{15}$ SPECIALE, R. Fundamentals of Aviation Law. 2006.

${ }^{16}$ IATA, "Režim univerzálnej zodpovednosti za medzinárodnú leteckú dopravu - Montrealský dohovor z roku 1999".
} 


\section{PRÁVNE ROZPRAVY ON-SCREEN II. - Sekcia verejného práva}

online vedecká konferencia - 13. november 2020

\section{Základné zásady ICAO}

V júli 2015 prijala Rada ICAO ako odpoved' na žiadost' Singapuru a d’alších členských štátov ICAO nezáväzné základné zásady pre cestujúcich v leteckej doprave. ${ }^{17}$ Základné zásady majú byt' "živým dokumentom", ktorý sa bude v budúcnosti upravovat'. To dokazuje, že tvorba globálnych politík v tejto oblasti zostáva pokroková, čo je zaujímavé, pretože medzinárodné právo ohl'adne zodpovednosti leteckého dopravcu existuje už viacero rokov. Nové základné zásady sú kategorizované podl'a troch rôznych stupňov: (1) pred cestou, (2) počas cesty a (3) po ceste. Kl'účové ustanovenia sú zhrnuté v nasledujúcej časti. Pred cestou by cestujúci/m:

(1) mali mat' prístup $\mathrm{k}$ informáciám o svojich právach, vrátane pomoci v prípade prerušenia služby, ak sú k dispozícii;

(2) mala byt' poskytnutá pomoc pri výbere - ponuka cien/služieb;

(3) mala byt' poskytnutá informácia s ciel’om zvýšit' povedomie o právach a potenciálnych možnostiach riešenia sporov; a

(4) mali byt' upozornený na všetky relevantné vlastnosti služby vrátane

a) ceny (cestovné, dane, poplatky a príplatky),

b) mali byt' poskytnuté všetky informácie vzt'ahujúce sa na výšku estovného

c) mala byt' poskytnutá informácia ohl'adne leteckej spoločnost'i.

Počas cesty by cestujúci mali:

(1) byt' informovaný o osobitných okolnostiach týkajúcich sa cesty, najmä ak existuje narušenie poskytovania služby;

(2) obdržat' náležitú starostlivost' $v$ prípade presmerovania a/alebo kompenzácie, ak je to stanovené príslušnými predpismi;

(3) obdržat' náležitú starostlivost' v prípade závažných problémov, ktoré ich ponechávajú v mimoriadne zranitel'nej pozícii; a

(4) mat' prístup k leteckej preprave nediskriminačným spôsobom s primeranou pomocou, ak ide o zdravotne postihnuté osoby.

${ }^{17}$ ICAO, "Rada ICAO prijala základné princípy ochrany spotrebitel’a a novú dlhodobú víziu pre liberalizáciu leteckej dopravy" (2015). 


\section{PRÁVNE ROZPRAVY ON-SCREEN II. - Sekcia verejného práva}

online vedecká konferencia - 13. november 2020

Počas cesty by cestujúci mali:

(1) obdržat' jednoznačnú odpoved' o postupe vybavovania st’ažností.

Na prvý pohl’ad sú hlavné zásady chápané ako usmernenia pre členské štáty ICAO, aby ich zvážili pri rozvíjaní nových ochranných opatrení a vnútroštátnych právnych predpisov. Otáznym zostáva, ako najlepšie zosúladit’ základné zásady s režimami práv cestujúcich v leteckej doprave, ktoré už existujú v mnohých štátoch a regiónoch. Znenie "tam, kde sú stanovené príslušnými predpismi" zdôrazňuje, že základné zásady neodkazujú na ustanovenia Montrealského dohovoru. Ako uvidíme v d’alšách častiach právne predpisy o právach cestujúcich v leteckej doprave sa zvyčajne snažia predvídat' čo sa stane s cestujúcim a čo sa stane s letom. Základné zásady tiež jasne zdôrazňujú potrebu, aby štáty vzdelávali spotrebitel’ov o ich právach, a aby letecké spoločnosti poskytovali úplnú transparentnost’ a zabezpečili jasnú komunikáciu. To naznačuje, že pokial' ide o leteckú dopravu, cestujúci sa môže nachádzat' vo viac ako jednej jurisdikcii počas jednej cesty. Pre cestujúceho by nemalo byt' t'ažké získat' informácie o svojich právach a podat' st'ažnost'. Na dosiahnutie plne funkčného systému je potrebná značná koordinácia na medzinárodnej úrovni. Hoci ICAO uznáva, že jednotlivé vlády by mali mat' flexibilitu na rozvoj vnútroštátnych režimov ochrany spotrebitel'a, varuje tiež, že všetky vnútroštátne predpisy by mali byt' vyvážené medzi poskytovaním ochrany spotrebitel'ov a zabezpečením konkurencieschopnosti priemyslu. Môžeme povedat', že prekrývajúce sa režimy vo všeobecnosti spôsobujú mätúcu situáciu cestujúcich v leteckej doprave. Tento režim vytvára pre letecké spoločnosti neisté prevádzkové prostredie. Bohužial', iniciatívy na ochranu spotrebitel'ov a ich vplyv na medzinárodnú leteckú dopravu ešte neboli úplne analyzované. Pravdepodobne na základe toho, že určitá štandardizácia globálneho prístupu k navrhovaniu práv cestujúcich v leteckej doprave prinesie väčšiu právnu istotu a schopnost' posúdit' finančné riziká, letecký priemysel voči IATA jednohlasne schválil základné zásady. Montrealský dohovor poskytuje "exkluzívny a jednotný právny rámec pre zodpovednost' leteckého dopravcu pri medzinárodnej leteckej preprave cestujúcich a batožiny vrátane škôd spôsobených meškaním letu". ${ }^{18}$ Zákonodarcovia, ktorí sa zaoberajú vytváraním režimov práv cestujúcich v leteckej doprave, sa snažia v zásade poskytnút’ pomoc a nápravu postihnutým cestujúcim, než aby sa zaoberali tým, čo sa skutočne stalo s ich letmi. To, ako uvidíme, podčiarkuje rozdiely

\footnotetext{
${ }^{18}$ ICAO "Ochrana spotrebitel'a: Spoločný prístup požadovaný medzi vládami a priemyslom".
} 


\section{PRÁVNE ROZPRAVY ON-SCREEN II. - Sekcia verejného práva}

online vedecká konferencia - 13. november 2020

medzi režimami práv cestujúcich $\mathrm{v}$ leteckej doprave a režimom zodpovednosti leteckého dopravcu. ${ }^{19}$

\section{Práva cestujúcich v EÚ a USA}

V tejto časti sústredíme našu pozornost' na práva cestujúcich v EÚ a USA ako aj na opatrenia prijaté na rozvoj práv cestujúcich v leteckej doprave. Pri pohl'ade na úpravu v EÚ môžeme konštatovat', že letecká doprava bola prvým sektorom, ktorý mal prospech z práv cestujúcich podl'a smernice 90/314/EHS (smernica o balíku cestovných služieb) ${ }^{20}$ a nariadenia (EHS) č. 295/91 (nariadenie o odmietnutí nástupu do lietadla) ktoré bolo nahradené nariadením (ES) č. 261/2004. ${ }^{21}$ Celkovo sa týmito právnymi predpismi EÚ usiluje dosiahnut' nielen vysoká úroveň ochrany spotrebitel’ov pre cestujúcich v leteckej doprave, ale tiež zdôrazňuje sa význam spravodlivej rovnováhy medzi záujmami leteckých dopravcov a cestujúcimi. Podl’a odôvodnenia 1 nariadenia 261/2004: "konanie spoločenstva v oblasti leteckej dopravy by sa malo, okrem iných vecí, zamerat' na zabezpečenie vysokej úrovne ochrany cestujúcich; okrem toho by sa mal vo všeobecnosti brat' plný zretel' na požiadavky ochrany spotrebitel'a."

Je to v súlade s čl. 12 a čl. 169 Zmluvy o fungovaní Európskej únie (ZFEÚ) o podpore záujmov spotrebitel'ov a zabezpečení vysokej úrovne ochrany spotrebitel'a. Ochrana spotrebitel’a je v centre záujmu politík EÚ. ${ }^{22}$ Nariadenie 261/2004 sa vzt'ahuje na všetky lety odlietajúce z letiska EÚ a na všetkých dopravcov EÚ; lety prevádzkované leteckými dopravcami z krajín mimo EÚ smerujúce do EÚ nepatria do jeho pôsobnosti. Súdny dvor (SDEÚ) sa niekol'kokrát v reakcii na žiadosti predložené vnútroštátnymi súdmi členských štátov zaoberal zlučitel'nost'ou práv cestujúcich s odškodnením v prípade meškania alebo zrušenia letov podl’a spoločných pravidiel s právami cestujúcich podla Montrealského dohovoru. ${ }^{23} \mathrm{~V}$ skutočnosti bolo v tejto oblasti prijatých viacero rozsudkov zo strany Súdneho

\footnotetext{
19 FUNTA, R. Medzinárodné právo/International law/Internationales recht/Diritto internazionale/ Международное право. 2010.

${ }^{20}$ Smernica Rady z 13. júna 1990, o balíku cestovných, dovolenkových a výletných služieb.

${ }^{21}$ Nariadenie Európskeho parlamentu a Rady (ES) č. 261/2004 z 11. februára 2004, ktorým sa ustanovujú spoločné pravidlá systému náhrad a pomoci cestujúcim pri odmietnutí nástupu do lietadla, v prípade zrušenia alebo vel'kého meškania letov a ktorým sa zrušuje nariadenie (EHS) č. 295/91Text s významom pre EHP.

${ }^{22}$ PROCHÁZKA, R. - ČORBA, J. Právo Európskej únie. 2006.

${ }^{23}$ Rozsudok Súdneho dvora (vel'ká komora) z 23. októbra 2012, C-581/10 a C-629/10, Emeka Nelson a i. proti Deutsche Lufthansa AG a TUI Travel plc a i. proti Civil Aviation Authority, EU:C:2012:657.
} 


\section{PRÁVNE ROZPRAVY ON-SCREEN II. - Sekcia verejného práva}

online vedecká konferencia - 13. november 2020

dvora, ktoré mali významný vplyv na výklad nariadenia 261/2004 vnútroštátnymi orgánmi na presadzovanie práva a vnútroštátnymi súdmi. Rozhodnutia sa uplatňujú priamo a preto sú právne záväzné pre letecké spoločnosti. Však pokial' neexistuje spoločný prístup $\mathrm{k}$ tejto judikatúre, leteckí dopravcovia, cestujúci, ako aj vnútroštátne orgány presadzovania práva nevedia vždy, ako uplatňovat' tieto rozhodnutia. To viedlo k rozdielnym výkladom pravidiel a teda k rozdielom v uplatňovaní nariadenia v členských štátoch. Treba zdôraznit', že práva udelené cestujúcim v leteckej doprave podl'a nariadenia 261/2004 sú v súlade s platnými medzinárodnými právnymi predpismi, najmä Montrealským dohovorom z roku 1999. Podl’a názoru Súdneho dvora sú požiadavky platit’ náhradu cestujúcim za meškanie pri príchode a poskytnút' pomoc cestujúcim v prípade oneskorenia pri odchode zlučitel'né s Montrealským dohovorom. Súdny dvor rozhodol, že: "štandardizované a okamžité opatrenia pomoci a starostlivosti nie sú samy osebe prekážkou toho, aby dotknutí cestujúci v prípade, ked’ im to isté meškanie spôsobilo okrem iného škody zakladajúce nárok na ich náhradu, mohli podat' žaloby o náhradu týchto škôd za podmienok upravených Montrealským dohovorom."24 Thijssen tvrdí, že "súdne spory v rozhodnutiach Sturgeon, Nelson a McDonagh sú dostatočným dôkazom toho, že nariadenie je naliehavo potrebné revidovat'." ${ }^{25}$ Tieto rozhodnutia budú podrobnejšie popísané nižšie. Kritika z obidvoch strán (spotrebitel’ov a priemyslu) sa zameriava na obavy, že interpretácie pravidiel EÚ, ktoré sa pravdepodobne niekedy odlišujú, môžu viest' $\mathrm{k}$ nedostatku právnej istoty, ${ }^{26}$ a preto podporujú zmätok medzi právami cestujúcich v leteckej doprave a zodpovednost'ou leteckého dopravcu. Európska komisia navrhla v roku 2013 niekol'ko zmien v nariadení č. 261/2004 s ciel'om objasnit' právny stav, najmä pokial' ide o takzvané mimoriadne okolnosti. Legislatívny návrh nedosiahol vel'ký pokrok. Naopak, Európsky parlament a Európska komisia sa snažia posilnit’ existujúce práva cestujúcich v leteckej doprave. Európska komisia vo februári 2016 uverejnila plán prípravy oznámenia o interpretačných usmerneniach k nariadeniu 261/2004; 27-stranové oznámenie Európskej komisie bolo uverejnené v júni $2016 .^{27}$

\footnotetext{
${ }^{24}$ Rozsudok Súdneho dvora (vel'ká komora) z 10. januára 2006, C-344/04, The Queen, na žiadost' International Air Transport Association a European Low Fares Airline Association proti Department for Transport, EU:C:2006:10. Body. 43 a 45-47.

25 THIJSSEN, Ch. The Montreal Convention, EU Regulation 261/2004, and the Sturgeon Doctrine: How to Reconcile the Three?" 2013.

${ }^{26}$ BOGUSZAK, J. - ČAPEK, J. - GERLOCH, A. Teorie práva. 2004; FÁBRY, B. - KASINEC, R. - TURČAN, M. Teória práva. 2019.

${ }^{27}$ Oznámenie Komisie: Výkladové usmernenia k nariadeniu Európskeho parlamentu a Rady (ES) č. 261/2004, ktorým sa ustanovujú spoločné pravidlá systému náhrad a pomoci cestujúcim pri odmietnutí nástupu do lietadla,
} 


\section{PRÁVNE ROZPRAVY ON-SCREEN II. - Sekcia verejného práva}

online vedecká konferencia - 13. november 2020

Oznámenie Komisie, výkladové usmernenia k nariadeniu Európskeho parlamentu a Rady (ES) č. 261/2004, ktorým sa ustanovujú spoločné pravidlá systému náhrad a pomoci cestujúcim pri odmietnutí nástupu do lietadla, v prípade zrušenia alebo vel'kého meškania letov, a k nariadeniu Rady (ES) č. 2027/97 o zodpovednosti leteckého dopravcu v prípade nehôd, zmenenému nariadením Európskeho parlamentu a Rady (ES) č. 889/2002 To nadväzuje na vyhlásenie z decembra 2015 "Stratégia v oblasti letectva pre Európu." ${ }^{28}$ V interpretačných usmerneniach sa zdôrazňuje význam výkladu nariadenia 261/2004 pre právo EÚ v oblasti práv cestujúcich $\mathrm{v}$ leteckej doprave. $\mathrm{V}$ minulosti cestujúci $\mathrm{v}$ leteckej doprave nemali výhodu jednotného výkladu, uplatňovania a presadzovania ich práv v rámci EÚ. Ďalším bodom interpretačných usmernení je zabezpečit’ väčšiu jednotnost' práv cestujúcich v leteckej doprave vo všetkých členských štátoch EÚ a vo všetkých tretích krajinách, v ktorých príslušné letecké spoločnosti profitujú z trhu leteckej dopravy EÚ vo vzt’ahu k dvojstranným a mnohostranným dohodám o leteckých službách. S ciel'om splnit' svoju povinnost' vyplývajúcu z právnych predpisov EÚ musí byt' letecký dopravca informovaný o ostatných režimoch práv cestujúcich v leteckej doprave v štátoch, v ktorých pôsobí. Napríklad, ak je služba cestujúceho prerušená pri letoch, ktoré odlietajú z letiska mimo EÚ (napr. Miami International, MIA) smerujúceho do EÚ (napr. Wien Schwechat, WIE) prostredníctvom európskeho dopravcu (napr. Austrian), môže cestujúceho nárok na určité práva podliehat’ právu USA. Aby neprichádzalo ku kompenzácii cestujúceho podl’a nariadenia 261/2004, musí sa preukázat', že postihnutý cestujúci sa už dovolal svojich nárokov podl’a práva USA. Táto koordinácia a práca smerom k vnútornému a vonkajšiemu zosúladeniu práv cestujúcich $\mathrm{v}$ medzinárodnom letectve je rozhodujúca. V skutočnosti riešenie nedostatkov a nezrovnalostí v právnych predpisoch EÚ nekoordinovaným spôsobom spôsobuje viac roztrieštenosti a zhoršuje aktuálny stav. V USA Ministerstvo dopravy zaviedlo v roku 2009 práva cestujúcich v leteckej doprave ako (prvú) rozšírenú ochranu cestujúcich v leteckej doprave. Druhým predpisom, ktorý bol vydaný v roku 2011, a tretím predpisom bol vytvorený americký letecký zákonník cestujúcich (APBOR). Účelom tohto predpisu je zmiernit' t’ažkosti cestujúcich v leteckej doprave počas zdíhavých oneskorení a inak podporit' zodpovednost' leteckých dopravcov voči spotrebitel'om. APBOR je k dispozícii všetkým cestujúcim leteckej spoločnosti, ktorí lietajú na amerických a

\footnotetext{
v prípade zrušenia alebo vel'kého meškania letov, a k nariadeniu Rady (ES) č. 2027/97 o zodpovednosti leteckého dopravcu v prípade nehôd, zmenenému nariadením Európskeho parlamentu a Rady (ES) č. 889/2002.

28 Oznámenie Komisie Európskemu parlamentu, Rade, Európskemu hospodárskemu a sociálnemu výboru a Výboru regiónov, Stratégia v oblasti letectva pre Európu, SWD(2015) 261.
} 


\section{PRÁVNE ROZPRAVY ON-SCREEN II. - Sekcia verejného práva}

online vedecká konferencia - 13. november 2020

zahraničných leteských spojoch do a zo Spojených štátov. APBOR sa zaoberá bežnými prerušeniami prevádzky, ako sú oneskorenia, zrušenie a odklon letu, atd’. Cestujúci v leteckej doprave majú právo do 24 hodín zrušit’ rezerváciu vykonanú v omyle za splnenia určitých podmienok. Ak je cestujúci nedobrovol'ne "vyradený" zo svojho potvrdeného letu, t.j. ak je cestujúcemu "zamietnutý vstup na palubu lietadla" podl'a pravidiel EÚ a letecká spoločnost' zariadi náhradnú prepravu, ktorá má plánovaný prílet na konečné miesto určenia ako bol stanovený pôvodný čas príletu (medzi jednou a štyrmi hodinami na medzinárodných letoch), letecká spoločnost' musí zaplatit' cestujúcim sumu rovnajúcu sa $200 \%$ jednosmerného cestovného do konečného miesta určenia $v$ daný deň s maximálnou sumou 650 USD. Ak sa náhradnou prepravou cestujúci dostane na miesto určenia neskôr o viac ako dve hodiny (viac ako štyri hodiny pri medzinárodných letoch), alebo ak letecká spoločnost' neuskutoční žiadnu náhradnú prepravu, kompenzácia sa zdvojnásobí (400 percent jednosmerného cestovného, a maximálne 1300 USD). Podl’a APBOR, ak je z akéhokol’vek dôvodu let zrušený, podstatne oneskorený alebo naplánovaný na iný čas, má cestujúci právo na premerovanie letu bez dodatočných nákladov alebo získat’ plnú náhradu. Politika leteckých spoločností sa však líši od toho, čo predstavuje "podstatné" oneskorenie alebo zmenu plánu.

\section{Príklady režimov práv cestujúcich v leteckej doprave}

V tejto záverečnej časti článku poukazujeme na nasledovné štyri aspekty v leteckej doprave: bezpečnost', prerušenie dopravy, proporcionalita a rovnaké podmienky pre leteckých dopravcov. Sú to aspekty voblasti leteckej dopravy, ktoré by zákonodarcovia mali zohl'adňovat' pri koncipovaní právnych ežimov ochrany cestujúcich v leteckej doprave. Na prvé miesto zaradíme bezpečnost'. Je nesporné, že bezpečnost' a ochrana civilného letectva sú najvyššou prioritou členských štátov ICAO. Bezpečnost' letectva je skutočne v centre záujmu ICAO. Bezpečnost' zahŕňa širokú škálu činností v leteckej doprave, t.j. letovú spôsobilost' lietadiel a posádky, bezpečnost' dráhy, leteckú navigáciu atd'. Režimy ochrany spotrebitel'a by nikdy nemali "ohrozit' zdravie alebo bezpečnost". V leteckom priemysle vznikajú okolnosti, ktoré môžu mat' vplyv na rozhodnutie o odložení letu. Letecký dopravca a kapitán lietadla musia vždy najprv zvážit’ bezpečnost' cestujúcich a posádky pri realizácii svojho rozhodnutia. V nariadení č. 261/2004 sa ustanovuje, že leteckí dopravcovia majú povinnost' starat'sa 


\section{PRÁVNE ROZPRAVY ON-SCREEN II. - Sekcia verejného práva}

online vedecká konferencia - 13. november 2020

o cestujúcich, ktorým bol odmietnutý nástup na palubu, ale nie sú povinní platit' náhradu, ak je prerušenie spôsobené "mimoriadnou okolnost’ou". Právne predpisy neposkytujú výpočet mimoriadnych okolností, ktoré v minulosti ponechali priestor na dost' široký výklad leteckými spoločnost’ami. V nadväznosti na rozhodnutie Súdneho dvora vo veci Friederike WallentinHermann/Alitalia sa letecké spoločnosti už nemôžu spoliehat' na článok 5 (3) nariadenia č. 261/2004 "mimoriadne okolnosti" v prípade "technických problémov", ktorým sa dalo vyhnút', ak by sa prijali všetky primerané opatrenia. Technické problémy, ktoré sú bežné alebo neodmyslitel'né v leteckej doprave, nebudú leteckým spoločnostiam oslobodené. Na druhej strane prípad Wallentin-Hermann/Alitalia a Aurora Sousa Rodríguez/Air France SA dramaticky zúžili definíciu mimoriadnych okolností. Prípady Christopher Sturgeon/Condor Flugdienst GmbH a Stefan Böck a Cornelia Lepuschitz/Air France $S A^{29}$ boli potvrdené Vel'kou komorou Súdneho dvora v roku 2012 vo veci Emeka Nelson/Deutsche Lufthansa. ${ }^{30}$ Od prípadu Sturgeon majú letecké spoločnosti tendenciu nezrušit' dlhé oneskorené lety, ale umožnia cestujúcim zotrvat' v omeškaní (v prípadoch Sturgeon dvadsat'dva a dvadsat'pät' hodín), aby zabránili povinnosti zaplatili náhradu podl’a čl. 5 a 7 nariadenia č. 261/2004". Vo svojom rozsudku preto Súdny dvor rozšíril na základe zásady rovnakého zaobchádzania právo na náhradu škody podl’a čl. 7 nariadenia č. 261/2004, ktoré sa vzt'ahuje na cestujúcich na zrušených letoch, na cestujúcich na letoch s oneskorením trvajúcim tri hodiny alebo viac. Súdny dvor v rozsudku Sturgeon zastával názor, že strata času spojená s meškaním predstavuje "nepríjemnost", na ktorú sa vzt’ahuje nariadenie č. 261/2004, na rozdiel od "škody", pre ktoré Montrealský dohovor poskytuje základ pre prípadný nárok. Režimy ochrany spotrebitel'a by mali umožňovat' zváženie dôsledkov masívnych prerušení. Jedným z dobrých príkladov masívneho narušenia leteckej dopravy je zatvorenie vzdušného priestoru kvôli rizikám spojených so vznikom sopečných erupcií. Sopka Eyjafjallajökull na Islande eruptovala 20. marca 2010. Vzdušný priestor nad väčšinou Európy bol uzavretý z dôvodu potenciálnych rizík pre lietadlá. Desat'tisíce letov boli zrušených a v dôsledku toho boli postihnuté milióny cestujúcich. Jeden írsky cestujúci uviazol v Portugalsku a neskôr si voči spoločnosti Ryanair uplatňoval nárok na preplatenie svojich výdavkov. Tie boli odmietnuté z dôvodu, že erupcia bola mimoriadnou

\footnotetext{
${ }^{29}$ Rozsudok Súdneho dvora (štvrtá komora) z 19. novembra 2009, C-402/07 a C-432/07, Christopher Sturgeon, Gabriel Sturgeon a Alana Sturgeon proti Condor Flugdienst GmbH ( $\underline{\mathrm{C}-402 / 07})$ a Stefan Böck a Cornelia Lepuschitz proti Air France SA (C-432/07), EU:C:2009:716.

30 Rozsudok Súdneho dvora (vel'ká komora) z 23. októbra 2012, C-581/10 a C-629/10, Emeka Nelson a i. proti Deutsche Lufthansa AG a TUI Travel plc a i. proti Civil Aviation Authority, EU:C:2012:657.
} 


\section{PRÁVNE ROZPRAVY ON-SCREEN II. - Sekcia verejného práva}

online vedecká konferencia - 13. november 2020

okolnost'ou, ktorá spôsobila zatvorenie vzdušného priestoru, čo bolo to mimo kontroly leteckej spoločnosti. Dublinský súd predložil Súdnemu dvoru otázku, v ktorej sa pýtal, či by to mohlo byt' interpretované ako mimoriadna okolnost', ktorá zbavuje leteckú spoločnost' povinnosti úhrad nákladov. Súdny dvor uviedol, že "Vel'ké prerušenia môžu zahŕňat' situácie vyplývajúce z okolností mimo kontroly prevádzkovatel’a, ktoré majú taký rozsah, že vedú k viacerým zrušeniam a/alebo oneskoreniam letov ... [napr. ] meteorologické alebo prírodné javy vo vel'kom rozsahu vrátane hurikánov, sopečných erupcií, zemetrasení, povodní, politickej nestability alebo podobných udalostí ...". Súdny dvor uviedol odkaz na predchádzajúcu judikatúru, že zatial' čo leteckí dopravcovia sú oslobodení od povinnosti platit' náhradu podl'a čl. 7 v prípade mimoriadnych okolností, ich povinnost' poskytovat' starostlivost' cestujúcim podl'a čl. 9 zostáva v každom prípade zachovaná. Sopečná erupcia však predstavovala mimoriadne okolnosti. Spoločnost' Ryanair bola teda zaviazaná splnit' si svoju povinnost' starat' sa o cestujúcich.

Naopak, nároky uplatnené v rámci amerického APBORu by pravdepodobne neboli úspešné z dôvodu, že sopečná erupcia je mimo kontroly leteckého dopravcu. Zatial' čo letecký dopravca je povinný podniknút' všetky primerané kroky, aby zabránil oneskoreniam a zrušeniam letov, nebude zodpovedný za škody spôsobené oneskorením alebo zrušením letov v situáciách súvisiacich $\mathrm{s}$ uzavretím vzdušného priestoru. Toto je tiež pozícia podl’a Montrealského dohovoru, v zmysle ktorého: "dopravca nenesie zodpovednost' za škodu spôsobenú oneskorením, ak preukáže, že on a jeho zamestnanci prijali všetky opatrenia, ktoré by mohli byt' odôvodnene požadované, aby sa predišlo škodám, alebo že nebolo možné, aby prijali takéto opatrenia". Na prvý pohl'ad sa zdá, že táto situácia spôsobuje zmätočné situáciu pre štáty a leteckých dopravcov. Zmluvné štáty Montrealského dohovoru, ktoré sú tiež členskými štátmi EÚ, sa dostali do pozície medzi požiadavky medzinárodného práva a práva EÚ. ${ }^{31}$ IATA a Európska asociácia nízkonákladových leteckých spoločností podali na Vrchný súd pre Anglicko a Wales súdne preskúmanie v súvislosti s vykonávaním nariadenia 261/2004. Žalobcovia v tomto ohl'ade tvrdili, že nariadenie č. 261/2004 nebolo v súlade s medzinárodným právom, konkrétne s ustanoveniami Montrealského dohovoru. Súd uviedol, že pomoc a starostlivost' o cestujúcich, ktoré predpokladá čl. 6 nariadenia č. 261/2004 v prípade vel'kého meškania letu, predstavujú štandardné a okamžité kompenzačné opatrenia. Systém v zmysle čl.

\footnotetext{
${ }^{31}$ VALEŠOVÁ, T. Vztah mezinárodního práva a vnitrostátního práva, vztah práva Evropských Společenství, Evropské Unie a vnitrostátního práva. 2003.
} 


\section{PRÁVNE ROZPRAVY ON-SCREEN II. - Sekcia verejného práva}

online vedecká konferencia - 13. november 2020

6 jednoducho funguje v skoršom štádiu ako systém, ktorý vyplýva z Montrealského dohovoru. Napriek tomu, že Montrealský dohovor v čl. 29 stanovuje výlučnost' pre nároky vyplývajúce z jeho ustanovení, súd sa domnieva, že nariadenie 261/2004 je jednotným právom, pretože pôsobí v skoršom štádiu a predstavuje doplnok k nárokom v zmysle Montrealského dohovoru. V konečnom dôsledku budú spotrebitelia platit' účty v prospech "dodatočnej" ochrany EÚ.

Nové princípy ICAO však stanovujú, že cestujúci sa môžu nachádzat' v situáciách značného narušenia letovej prevádzky, a preto letecké spoločnosti, prevádzkovatelia letísk a všetky zainteresované strany vrátane vládnych orgánov by mali vopred plánovat' mechanizmy, aby sa cestujúcim dostala primeraná starostlivost' a pomoc. V čase, ked' sa objavujú časté výskyty sopečných erupcií, hurikánov, snehových búrok (alebo aktuálne pandémie COVID-19), je súčasný nedostatok globálnej istoty v oblasti ochrany cestujúcich v leteckej doprave problematický. Podl'a Montrealského dohovoru "Montrealský dohovor" vytvára exkluzívny a jednotný právny rámec pre zodpovednost' leteckého dopravcu v medzinárodnej leteckej doprave cestujúcich a batožiny vrátane škôd spôsobených meškaním letu. Napriek tomu trvalé zvyšovanie dopytu po leteckej doprave (po pandémii COVID-19) bude znamenat', že viac l'udí bude využívat' leteckú dopravu, a preto sa zvýši počet cestujúcich pravdepodobne ovplyvnených mimoriadnymi okolnost’ami. V rámci EÚ existuje nedostatok transparentnosti a zosúladený prístup medzi členskými štátmi. Podl’a ICAO by režimy ochrany spotrebitel'a mali odrážat' aj zásadu proporcionality. ${ }^{32}$ Právo EÚ stanovuje vel'mi vysoký prah ochrany spotrebitel'ov ${ }^{33}$ pre cestujúcich v leteckej doprave. Ako už bolo uvedené, informovanost' spotrebitel'ov, vybavovanie st’ažností a ich presadzovanie tiež spochybňujú účinnost' nariadenia 261/2004. Niektorí kritici tvrdia, že práva cestujúcich v leteckej doprave sú príliš vel'korysé, a preto sú neprimerané $\mathrm{k}$ tomu, čo je $\mathrm{k}$ dispozícii v rámci iných režimov práv cestujúcich. Hoci to môže byt' pravda v globálnom meradle, ako sme videli v prípade masívnych prerušení, pozícia kritikov môže byt' napadnutá, ked’ sa zvažujú iné režimy EÚ. Cestovanie leteckou dopravou zvyčajne neobsahuje náhradu. Ak je let omeškaný alebo zrušený, postihnutý cestujúci nemusí mat’ k dispozícii iný spôsob dopravy. Pre železničnú prepravu, na ktorú sa vzt’ahuje právo EÚ, môžu cestujúci bez straty práva prepravy: Žiadat’ kompenzáciu za oneskorenia od železničného podniku, ak sa stretáva s meškaním medzi miestom nástupu a

32 SYllOVÁ, J. - PÍTROVÁ, L. - PALDUSOVÁ, H.; a kol. Lisabonská smlouva, komentář. 2010; BORCHARDT, K. D. Die Rechtlichen Grundlagen der Europäischen Union. 2020. IVOR, J. - KLIMEK, L. ZÁHORA, J. Trestné právo Európskej únie a jeho vplyv na právny poriadok Slovenskej republiky. 2013.

${ }^{33}$ KARAS, V. - KRÁLIK, A. Právo Európskej únie. 2012. 


\section{PRÁVNE ROZPRAVY ON-SCREEN II. - Sekcia verejného práva}

online vedecká konferencia - 13. november 2020

miestom určenia... Minimálne náhrady za meškanie sú nasledovné: (a) 25\% ceny cestovného lístka za meškanie 60 až 119 minút, (b) 50\% ceny cestovného lístka za meškanie 120 minút alebo viac. Ak sa cesta uskutočňuje po mori alebo po vnútrozemských vodných cestách, cestujúci môžu požiadat' o náhradu bez straty práva na prepravu: Ak čelia omeškaniu príchodu do konečného miesta určenia, minimálna výška kompenzácie je $25 \%$ ceny cestovného lístka za meškanie aspoň: (a) 1 hodinu v prípade plánovanej cesty v trvaní do 4 hodín; (b) 2 hodiny $\mathrm{v}$ prípade plánovanej cesty dlhšej ako 4 hodiny, ale nie dlhšej ako 8 hodín; (c) 3 hodiny v prípade plánovanej cesty dlhšej ako 8 hodín, ale nie dlhšej ako 24 hodín; alebo (d) 6 hodín v prípade plánovanej cesty dlhšej ako 24 hodín. Ak oneskorenie prekročí dvojnásobok času stanoveného v písmenách a) až d), kompenzácia je 50\% ceny lístka. Nakoniec pre cestujúcich prepravovaných autobusmi právne predpisy EU' ${ }^{34}$ stanovujú, že prepravcovia by mali znížit' nepríjemnosti cestujúcich $\mathrm{v}$ dôsledku zrušenia alebo významného oneskorenia ich cesty. Cestujúci by tiež mali mat' možnost' zrušit' svoju cestu a uhradit' svoje cestovné lístky alebo pokračovat' v ceste alebo získat' presmerovanie za uspokojivých podmienok. Ak dopravcovia neposkytnú cestujúcim potrebnú pomoc, cestujúci by mali mat’ právo na finančnú kompenzáciu. To, čo majú všetky tri vyššie uvedené "režimy" spoločné, je spojenie medzi cenou lístka a kompenzáciou. Platí, že situácia cestujúcich postihnutých v dôsledku zrušenia alebo významného oneskorenia ich cesty na jednej z týchto iných foriem dopravy nemôže byt' porovnatel'ná so situáciou cestujúceho v leteckej doprave. Ako bolo uvedené vyššie, prístup americkej APBOR k kompenzácii nie je spojený s cenou letenky; je to trhová cena jednosmernej letenky, ktorá sa následne násobí. Bez ohl'adu na prístup k určovaniu odškodnenia bude postup závisiet' od existencie a dostupnosti primeraných mechanizmov vybavovania st’ažností.

\section{Záver}

Pokial’ ide o leteckú dopravu, základné zásady ICAO sa obmedzujú na to, aby sa cestujúci v leteckej doprave mohli spol'ahnút' na účinné postupy vybavovania st'ažností, ktoré sa im zrozumitel’ne oznámia. Z vyššie uvedenej diskusie sú zaujímavé rozdiely, ktoré prináša nariadenie 261/2004 o leteckých dopravcoch EÚ oproti APBOR pre leteckých dopravcov

\footnotetext{
${ }^{34}$ FUNTA, R. - GOLOVKO, L. - JURIŠ, F. Európa a európske právo. 2020.
} 


\section{PRÁVNE ROZPRAVY ON-SCREEN II. - Sekcia verejného práva}

online vedecká konferencia - 13. november 2020

z USA. V rámci EÚ existuje nedostatok konzistentnosti pri presadzovaní a uplatňovaní nariadenia 261/2004 v jednotlivých členských štátoch EÚ. Z pohl'adu medzinárodného práva je možné uznat', že zámery ICAO sú dobré. Vyššie uskutočnená analýza naznačuje, že pri neexistencii nového medzinárodného dohovoru o právach cestujúcich $\mathrm{v}$ leteckej doprave sa normy IATA a Montrealský dohovor môžu javit’ ako najvhodnejšie pre všetkých, s účinnou metódou riešenia sporov v zmluvných štátoch ICAO. Globálny priemysel potrebuje jednotný univerzálny systém zodpovednosti, ktorý upravuje medzinárodnú leteckú prepravu cestujúcich a nákladu. IATA preto vyzvala všetky ostatné krajiny, aby ratifikovali Montrealský dohovor s ciel'om dosiahnut' požadovanú úroveň jednotnosti v tomto sektore.

\section{ZOZNAM BIBLIOGRAFICKÝCH ODKAZOV}

\section{Monografie a učebnice:}

BOGUSZAK, J. - ČAPEK, J. - GERLOCH, A. Teorie práva. 2. vydání, Praha: Aspi, 2004. ISBN 978-80-73570-30-9.

BORCHARDT, K. D. Die Rechtlichen Grundlagen der Europäischen Union. 7. Auflage, Heidelberg: C.F.Müller, 2020. ISBN 978-3-8252-5278-6.

BARTSCH, I. International Aviation Law: A Practical Guide. 1st Edition, New York: Routledge, 2012. ISBN 978-14-0943-287-6.

FÁBRY, B. - KASINEC, R. - TURČAN, M. Teória práva. 2. vydanie, Bratislava: Wolters Kluwer, 2019. ISBN 978-80-571-0127-7.

FUNTA, R. - GOLOVKO, L. - JURIŠ, F. Európa a európske právo,. Brno: MSD, 2020. ISBN 978-80-7392-334-1.

FUNTA, R. Medzinárodné právo/International law/Internationales recht/Diritto internazionale/Международное право. Brno: Tribun EU, 2010. ISBN 978-80-7399-044-2.

HAMILTON, S. Practical Aviation Law. 5th Edition, Iowa: Iowa State University, 2011. ISBN 978-15-6027-763-7.

HAVEL, G. The Principles and Practice of International Aviation Law. Cambridge: Cambridge University Press, 2014. ISBN 978-11-0769-773-7.

IVOR, J. - KLIMEK, L. - ZÁHORA, J. Trestné právo Európskej únie a jeho vplyv na právny poriadok Slovenskej republiky. Žilina: Eurokódex, 2013. ISBN 978-80-8155-017-1. 


\section{PRÁVNE ROZPRAVY ON-SCREEN II. - Sekcia verejného práva}

online vedecká konferencia - 13. november 2020

KARAS, V. - KRÁLIK, A. Právo Európskej únie. 1. vydanie, Bratislava: C.H.Beck, 2012. ISBN 978-80-7179-287-1.

MAZÁK, J. - JÁNOŠÍKOVÁ, M. Základy práva Európskej únie. Bratislava: Wolters Kluwer, 2009. ISBN 978-80-8078-289-4.

MRÁZ, S. - POREDOŠ, F. - VRŠANSKÝ, P. Medzinárodné verejné právo, Bratislava: VO PF UK, 2003. ISBN 978-80-7160-175-6.

PROCHÁZKA, R. - ČORBA, J. Právo Európskej únie. Bratislava: Poradca podnikatel’a, 2006. ISBN 978-80-8893-162-1.

SPECIALE, R. Fundamentals of Aviation Law. 1st Edition, Columbus: McGraw-Hill Education, 2006. ISBN 978-00-7145-867-2.

SYLLOVÁ, J. - PÍTROVÁ, L. - PALDUSOVÁ, H.; a kol. Lisabonská smlouva, komentář, Praha: C.H.Beck, 2010. ISBN 978-80-89406-07-4.

SVOBODA, P. Úvod do evropského práva. 4. vydání, Praha: C.H.Beck, 2011. ISBN 978-807400-313-4.

\section{Periodiká a zborníky:}

THIJSSEN, Ch. The Montreal Convention, EU Regulation 261/2004, and the Sturgeon Doctrine: How to Reconcile the Three?” In: 12 Issues Aviation Law \& Policy, 2013.

VALEŠOVÁ, T. Vztah mezinárodního práva a vnitrostátního práva, vztah práva Evropských Společenství, Evropské Unie a vnitrostátního práva. Praha: Justiční akademie ČR, 2003. 